\title{
Apoptotic Effects of Beta-Carotene, Alpha-Tocopherol and Ascorbic Acid on PC-3 Prostate Cancer Cells
}

\section{Beta-Karoten, Alfa-Tokoferol ve Askorbik Asidin PC-3 Prostat Kanser Hücrelerine Apoptotik Etkileri}

\author{
Adnan Ayna \\ Department of Chemistry, Faculty of Sciences and Arts, Bingöl University, Bingöl, Turkey.
}

\section{ABSTRACT}

rostate cancer (PC) is one of the most commonly diagnosed cancer types being the second major reason of cancer associated death in male particularly over the age of 50. Accumulating scientific evidences suggest the role oxidative stress and reactive oxygen species (ROS) in prostate cancer. A variety of factors including carcinogenic molecules, infectious diseases and toxic compounds can induce ROS production which turns into a strong contribution to the disturbed homeostasis and genetic mutation. Antioxidants can decrease the negative effects of ROS in vitro. Vitamin $C$ (Ascorbic acid, Asc), vitamin $A$ (beta carotenoids and retinoids, $\beta$-Crt) and vitamin $E$ (alpha tocopherol, $\alpha$-Toc) play an important role in inhibition of oxidative stress and diminishing of free radicals in the body. The aim of this study was to determine the anticancer effect of $\alpha$-Toc, $\beta$-Crt and Asc on PC-3 prostate cancer cells in vitro. This was carried out by cell proliferation, ROS and Lipid Peroxidation assay, caspase-3 and propidium iodide staining experiments. The findings suggest that these agents behave as prooxidant by lowering cell viability and increasing the production of ROS and LPO in prostate cancer. These oxidants induce apoptosis as supported by caspase-3 (the enzyme playing key role in programmed cell death) staining by displaying a marked increase in the expression level of caspase-3 enzyme.

\section{Key Words}

Prostate cancer; reactive oxygen species; apoptosis; caspase-3.

\section{öz}

rostat kanseri (PC), özellikle 50 yaşın üzerindeki erkeklerde kansere bağlı ölümlerin ikinci büyük nedeni olan ve en yaygın olarak teşhis edilen kanser tiplerinden biridir. Bilimsel çalışmalar oksidatif stres ve Reaktif oksijen türlerinin (ROS) prostat kanseri üzerindeki rolünü göstermektedir. ROS, kanserojen moleküller, enfeksiyon, toksi bileşikler gibi homeostaza ve genetik mutasyona neden olabilecek bileşikler tarafından üretilir. Antioksidanlar, ROS'un olumsuz etkilerini in vitro olarak azaltabilir. C vitamini (Askorbik asit, Asc), A vitamini (beta karotenoidler ve retinoidler, $\beta$-Crt) ve E vitamini (alfa tokoferol, $\alpha$-Toc) oksidasyonun önlenmesinde ve vücuttaki serbest radikallerin konsantrasyonunun azaltılmasında önemli rol oynar. Bu çalışmanın amacı, $\alpha-T o c, \beta-C r t$ ve Asc'nin PC-3 prostat kanseri hücreleri üzerindeki in vitro antikanser etkisini belirlemektir. Bu amaç, hücre çoğalması, ROS ve Lipid Peroksidasyon deneyi, kaspaz-3 ve propidium iyodür boyama deneyleri ile gerçekleştirildi. Bulgular, bu ajanların, prostat kanseri hücrelerinde hücre canlııı̆ını azaltarak ve ROS ve LPO üretimini artırarak proksidan olarak davrandığını göstermektedir. Bu oksidanlar kaspaz-3 (programlı hücre ölümünde rol alan önemli bir enzim) boyamasıyla desteklendiği üzere apoptozu kaspaz-3 enziminin ekspresyonunu artırarak indüklemiştir.

\section{Anahtar Kelimeler}

Prostat kanseri; reaktif oksijen türleri; apoptoz; kaspaz-3.

Article History: Received: Jan 2, 2020; Revised: Mar 15 2020; Accepted: Mar 15, 2020; Available Online: Apr 1, 2020.

DOI: https://doi.org/10.15671/hjbc.519212

Correspondence to: Department of Chemistry, Faculty of Sciences and Arts, Bingöl University, Bingöl, Turkey.

E-Mail: aayna@bingol.edu.tr 


\section{INTRODUCTION}

0 rostate cancer is one of the most common cancer types of men in the World $10 \%$ of which results in death [1]. Many studies have focused the relation between oxidative stress and prostate cancer [2-4]. The generation of reactive oxygen species (ROS) and changes in redox status are common biochemical phenomena in cancer cells. ROS can attack polyunsaturated fatty acids of lipid membranes and induce lipid peroxidation (LPO). An excessive increase in the amount of ROS and LPO induced by different prooxidants leads to oxidative stress and apoptosis leading to overcleaning of the cellular antioxidant defense system [5-6]. Antioxidants have been widely used as dietary supplements and have been investigated for their effectiveness in prevention of many diseases including various types of cancer. The vitamins C (Ascorbic acid, Asc), A (beta carotenoids and retinoids, $\beta$ - $C r t$ ) and $E$ (alpha tocopherol, $\alpha$-Toc) are known to act as antioxidants by delaying or inhibiting oxidation and reducing the concentration of free radicals in the body. In addition to their use in cancer prevention, supplemental antioxidants have usually been prescribed to cancer patients either by clinicians or patients themselves [7-8]. Vitamin E is reported as an efficient lipid soluble antioxidant that functions as a 'chain breaker' during lipid peroxidation process in cell membranes. It shows functionality by intercepting lipid peroxyl radicals (LOO') and terminating the lipid peroxidation chain reactions resulting in stable tocopheroxyl radical which is insufficiently reactive to initiate lipid peroxidation itself in normal circumstances, showing an essential criterion of a good antioxidant [9- 12]. Additionally, some studies demonstrate that vitamin E shows its antioxidant properties through scavenging LOO' in vivo as well as in vitro systems. Despite being good scavenger of lipid peroxyl, itis not an efficient scavenger of $\mathrm{OH}$ and alkoxyl radicals ('OR) in vivo [13].

Vitamin C or ascorbic acid, is a well-known water-soluble free radical scavenger. In addition to its role being a free radical scavenger, it has important function in regeneration of vitamin $E$ in cell membranes within combination with reducing antioxidant glutathione [14$16,9]$.

The precursors of vitamin A, $\beta$-Crt, are natural compounds with lipophilic properties. 500 different compounds of carotenoids have been reported until today. Most of the studied carotenoids have an extended system of conjugated double bonds, which is responsible for their antioxidant activity. Epidemiologic research in humans have demonstrated that $\beta$-Crt has an important role in cancer prevention. In addition to this, the carotenoids have also been demonstrated to have the ability of inhibiting free radical reactions. Among these carotenoids, $\beta$-Crt was shown to reduce tri chloromethylperoxyl radicals. $\beta$-Crt was also found to inhibit the oxidation of model compounds (tetralin and methyl linoleate) by peroxyl radicals [17].

The aim of this study was to determine the anticancer effect of $\alpha$-Toc, $\beta$-Crt and Asc on PC-3 prostate cancer cells in vitro and elucidate underlying molecular mechanism of the antioxidants. In this context, the effects of these antioxidants on cell viability, production of ROS and LPO and their relationship with apoptosis were evaluated in this study.

\section{MATERIALS and METHODS}

\section{Cell Culture}

Human prostate cancer cells [PC-3 (ATCC ${ }^{\circledR}$ CRL1435 ${ }^{\text {TM }}$ ) were cultured in complete endothelial growth media containing $10 \%$ fetal bovine serum, $1 \%$ penicillin-streptomycin (10000 units/ml, $10 \mathrm{mg} / \mathrm{ml}$ streptomycin). The cells were cultured in humidified incubator with $5 \%$ $\mathrm{CO} 2$ and checked every two or three days. Cells were checked for mycoplasma contamination by using EZPCR mycoplasma test kit (Biological Industries).

\section{Cell Proliferation Assay}

Water Soluble Tetrazolium-1 (WST-1) cell proliferation assay kit (Clontech Laboratories, USA) was used to investigate the effects of $\alpha$-Toc, $\beta-C r t$ and Asc on PC-3 cells. Experiments were carried out according to the procedure provided by the supplier. Initially 10.000 PC-3 cells were seeded in 96-well plate. After that the cells were treated with different doses of agents between 15 to $60 \mu \mathrm{g} / \mathrm{ml}$. Subsequently, $5 \mu \mathrm{l}$ of WST-1 was added into each well. After $4 \mathrm{~h}$ incubation, absorbance of each well was recorded at $450 \mathrm{~nm}$ (reference: 630 $\mathrm{nm}$ ) by SpectraMax Plus 384 Microplate Reader (Molecular Devices, USA).

\section{Intracellular ROS Detection}

The amount of ROS was measured by 2',7'-dichlorodihydrofluorescin diacetate (DCFH-DA). The cells were treated with $60 \mu \mathrm{g} / \mathrm{ml}$ of $\alpha$-Toc, $\beta$-Crt and Asc. $1 \times 106$ cells were harvested and incubated in the presence of $2 \mu \mathrm{M}$ 
DCFH-DA at $37^{\circ} \mathrm{C}$ for $1 \mathrm{~h}$. Fluorescence measurements were recorded by a spectrofluorometer (Perkin-Elmer LS-55, USA) at wavelengths of $485 \mathrm{~nm}$ (excitation) and $525 \mathrm{~nm}$ (emission).

\section{Lipid Peroxidation Assay}

The antioxidant activity of -Toc, $\beta$-Crt and Asc was evaluated by LPO assay measuring malondialdehyde as a malondialdehyde-thiobarbituric acid adduct as explained by Smith [18]. Malondialdehyde bis was used for standard graph preparation [18].

\section{Propidium lodide Staining for Apoptosis}

Cells were seeded and harvested in 96-well plate. Later, cells were treated with $60 \mu \mathrm{g} / \mathrm{ml}$ of $\alpha$-Toc, $\beta$-Crt and Asc. Then, the cells were washed with PBS twice. Propidium iodide was added to each well and cells were imaged by inverted microscope with fluorescence attachment (Olympus, JAPAN).

\section{Immunohistochemical Staining of Caspase-3}

Immunohistochemical staining was performed as exp lained in [19]. The cells containing dark brown nuclei or cytoplasm identified as caspase-3 (+) cells.

\section{RESULTS}

\section{Cell Viability}

The viability of $\alpha$-Toc, $\beta$-Crt and Asc on PC 3 cell line was determined by WST-1 assay. The results of representative experiments are shown (Figure 1). In general all antioxidants tested within this study decreased cell viability at concentrations of $60 \mu \mathrm{g} / \mathrm{ml}$ when compared to control.

\section{Intracellular ROS and LPO Analysis}

To determine whether these antioxidants could effect ROS production, a well-developed ROS assay was used. The results demonstrated that ROS production increased in comparison with non-treated prostate cancer cells (Figure 2a). Lipid peroxidation assay was used to assess oxidative stress by measuring the amount of malondialdehyde (MDA) in controls. The test results indicated a dose-dependent increase in MDA production. As shown in Figure $2 b$, the data revealed significant differences $(p<0.001)$ in MDA production at $60 \mu \mathrm{g} / \mathrm{ml}$ of $\alpha$-Toc, $\beta$-Crt and Asc compared to the control $(0 \mu \mathrm{g} / \mathrm{ml})$.

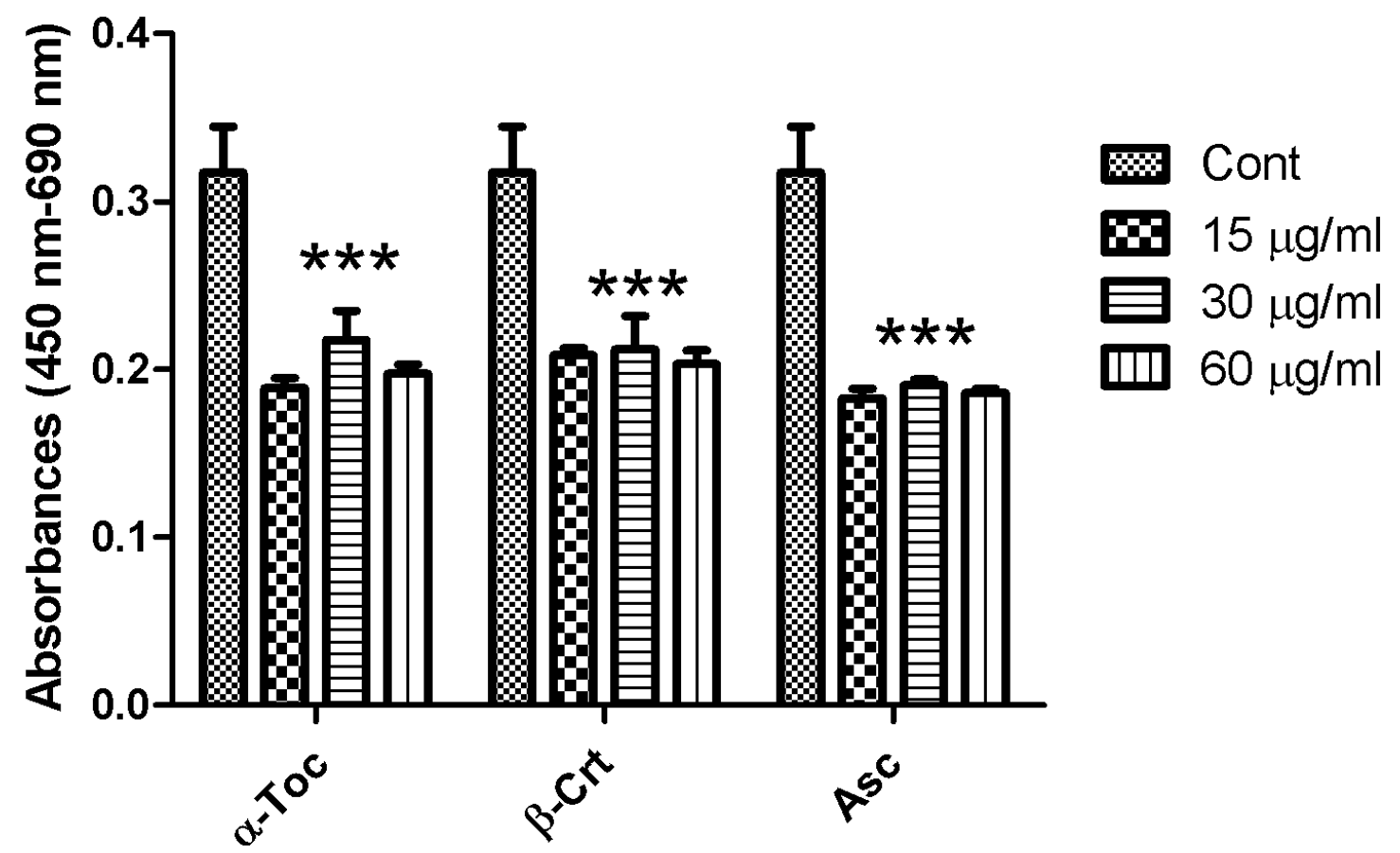

Figure 1. The effect of $\alpha$-Toc, $\beta$-Crt and Asc in PC-3. Cell viability was examined by WST-1 assay. The data were expressed by mean \pm SEM $(n \geq 3)$. ***p $<0.001$ Cont vs all antioxidants 


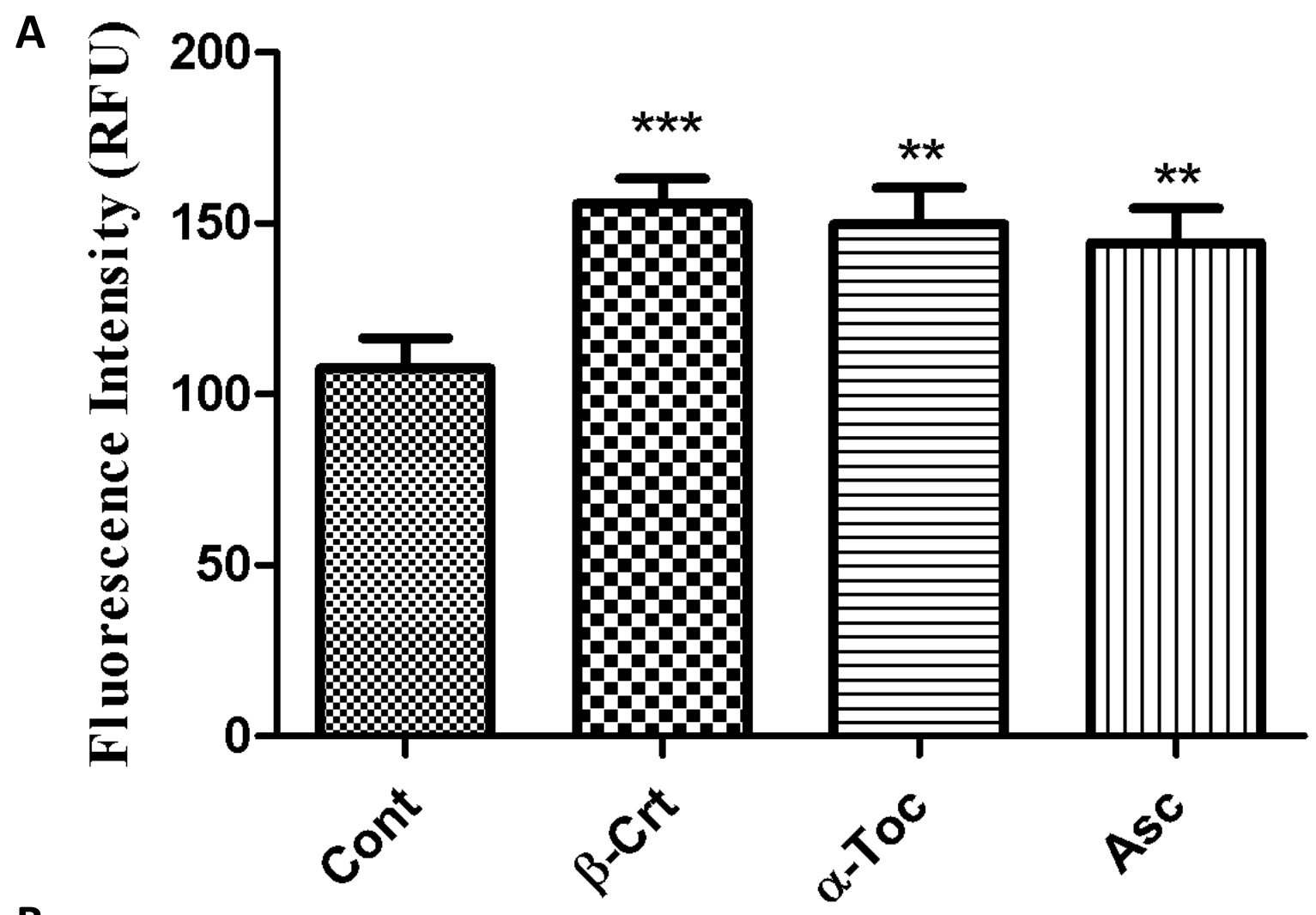

B

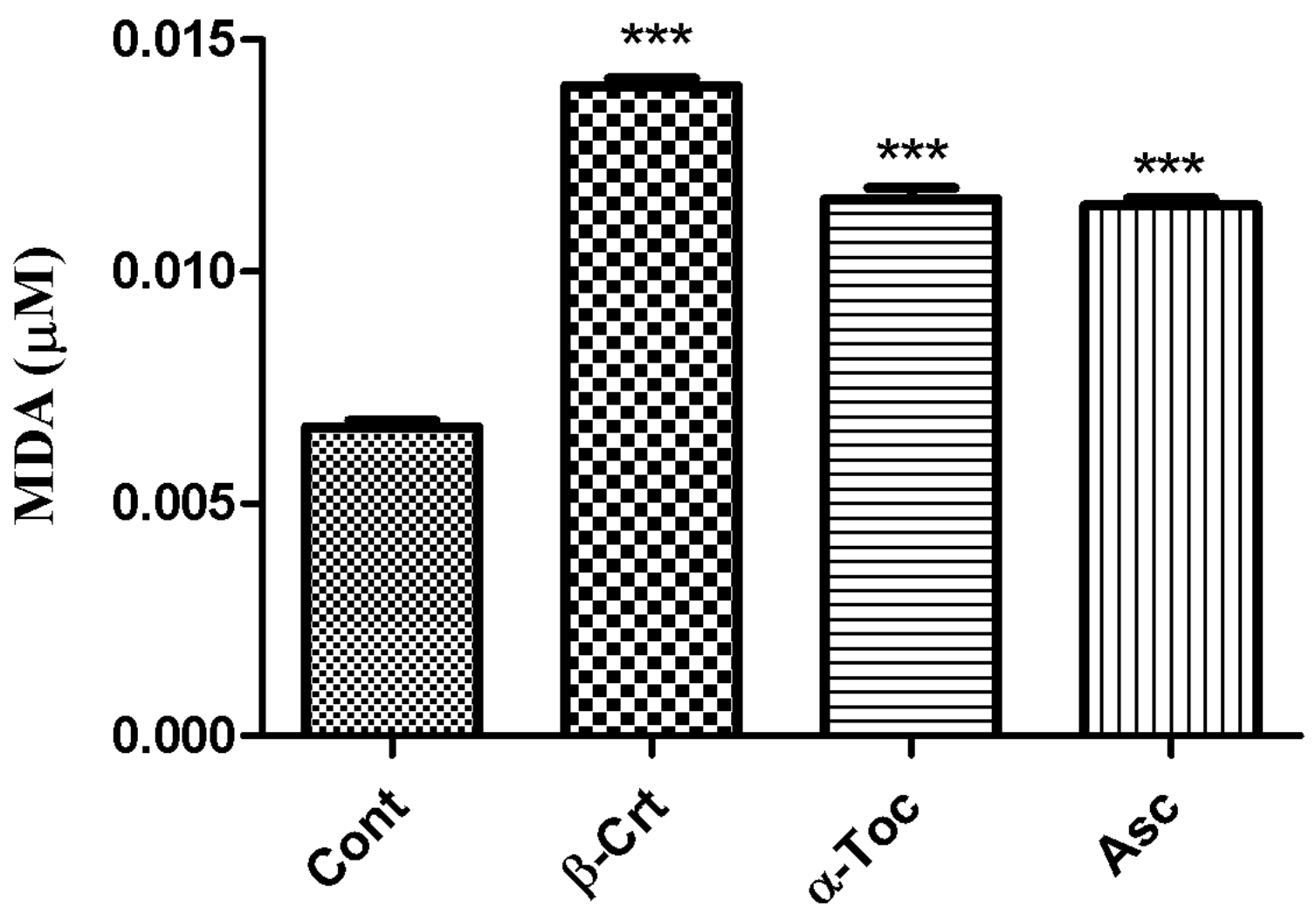

Figure 2. The effect of $\alpha$-Toc, $\beta$-Crt and Asc on ROS (a) generation and LPO levels (b) in PC-3. Cells were exposed to antioxidants. Data were presented by mean \pm SEM. $(n=3)$. 


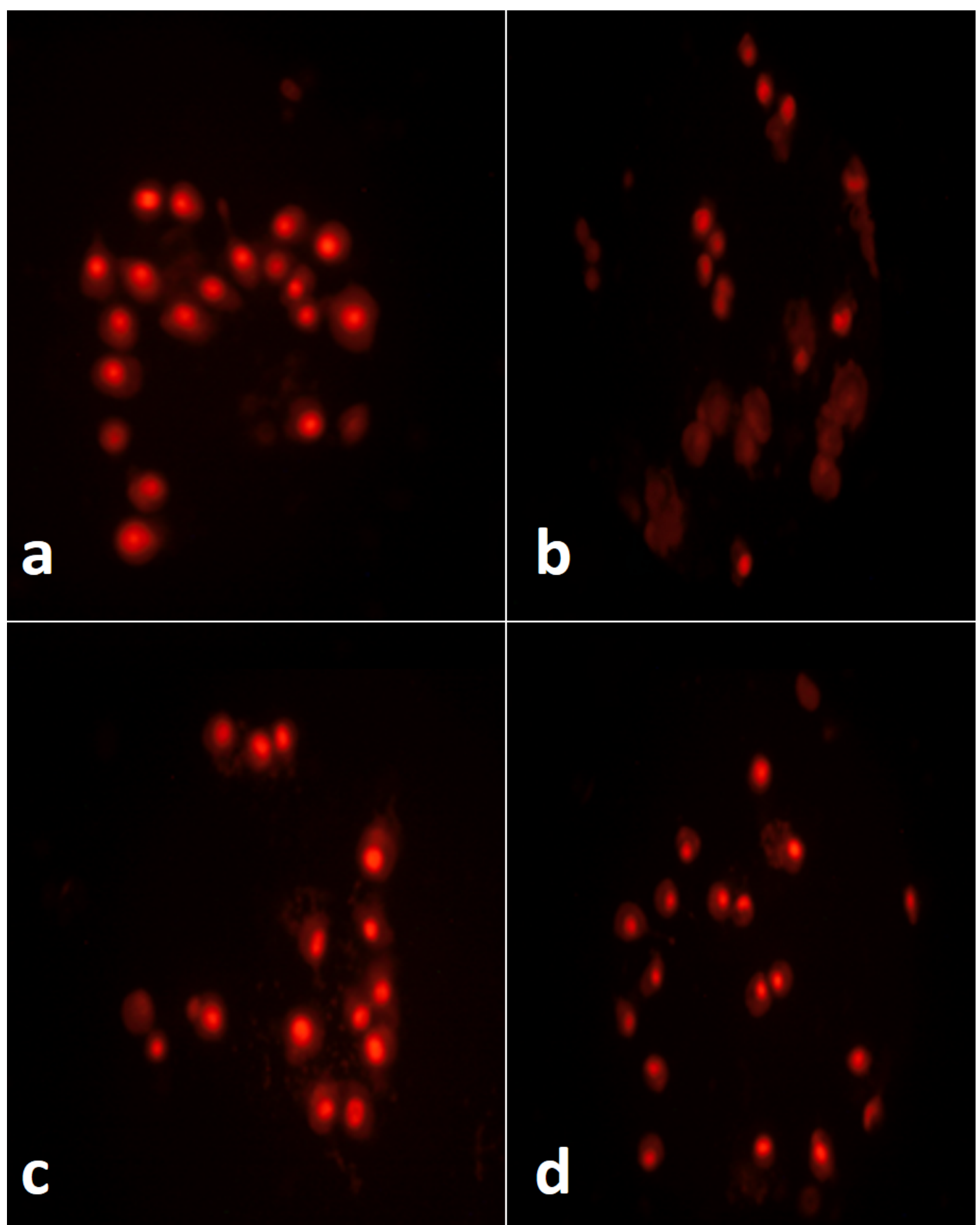

Figure 3. The effect of $\alpha$-Toc (c), $\beta$-Crt (a) and Asc compared (d) to the control $(0 \mu \mathrm{g} / \mathrm{ml})$ (a) on apoptosis evidenced by propidium staining.

\section{Propidium iodide Staining}

Propidium iodide staining of cellular nuclei was used as a marker for cell death during the $24 \mathrm{~h}$. Cells are characterized by the typical nuclear modifications. In apop- totic stages, the cells are characterized by a shrink in nucleus. Apoptotic cells were less colored as shown in (Figure 3) 


\section{Caspase-3 Staining}

To further investigate that the cell death indicated by propidium iodide staining was arisen from apoptotic cascade, immunohistochemical staining of the cells was carried for the active form of caspase 3-a downstream effector of apoptosis-using mouse monoclonal caspase-3 p11 antibody (diluted at 1:500; Santa Cruz Biotechnology, USA). The results indicate the presence of caspase 3 positive represented by black dot shown by arrows (Figure 4). This further demonstrates that the effect of these antioxidants is through apoptotic pathway.

\section{DISCUSSION}

Cancer, is one of the major causes of mortality in the world. Recently, it was reported that cancerous cells are linked with high ROS levels, as a result of metabolic, genetic and microenvironment-dependent changes. ROS are generated through the metabolism of oxygen during mitochondrial aerobic respiration. High amount of ROS in cells damage or mutate the DNA of the cells [20].

Despite being studied widely, there has been no precise therapy for prostate cancer to date. Therefore, novel treatment strategies are needed. Regular consumption of natural flavonoids may be associated with a decreased risk of the cancers.

One of the most important antioxidant that fights against lipid peroxidation of cell membranes is Vitamin E. It can alter the oxidative stress biomarkers positively [21].

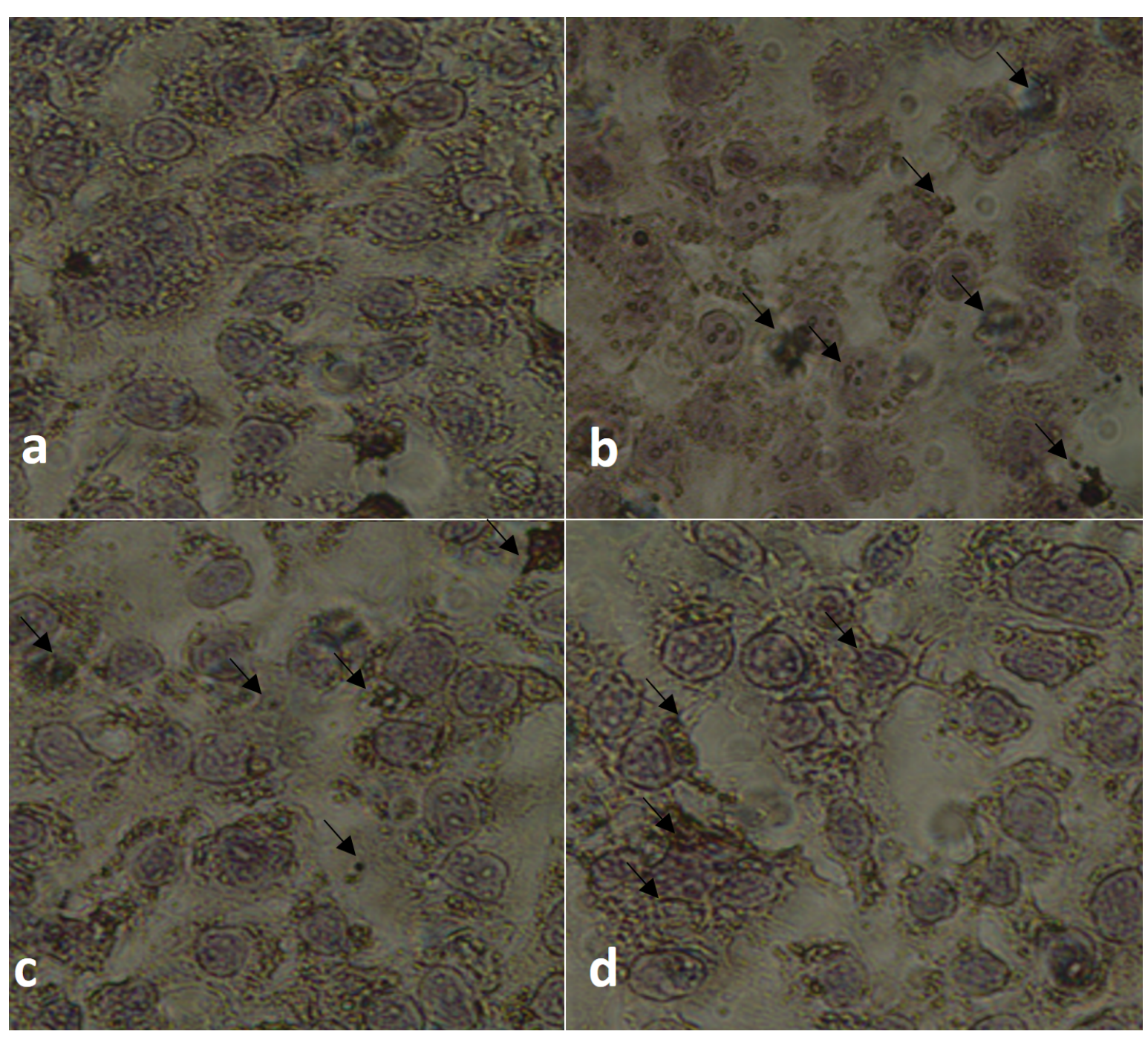

Figure 4. The effect of $\alpha-\operatorname{Toc}(\mathrm{c}), \beta-\mathrm{Crt}$ (a) and Asc compared (d) to the control $(0 \mu \mathrm{g} / \mathrm{ml})$ (a) on apoptosis related active caspase-3 in PC-3. The cells were imaged under the inverted light microscope and caspase-3 expressing cells were clearly visible with their dark brown color. 
Previous studies demonstrated that, $\beta$-CRT and retinol supplementation had no effect on the prostate cancer. It was reported that daily supplementation with selenium (200 $\mu \mathrm{g})$, vitamin E (400 IU) or both for decreased incidence of prostate cancer in men aged over 50 years. On the other hand, supplementation with 400 IU vitamin E every other day, $500 \mathrm{mg}$ vitamin C every day or a combination of the two were reported to decrease the incidence of cancer in male US physicians aged 50 years or more [6, 22-24].

Recent studies reported that these antioxidants can be behaved as an antioxidant or prooxidant, depending on the redox potential of the biological environment in which it involves [25]. At low concentrations, the antioxidants are reported to act as an antioxidant, inhibiting free radical production, while at high concentrations, they presumably behave as a prooxidant, propagating free radical-induced reactions, consuming endogenous antioxidants and inducing DNA damage. Herein the focus of this study was causing oxidative stress and apoptosis of PC- 3 by $\alpha-T o c, \beta-C r t$ and Asc. It was found that these antioxidants led to an increase in the LPO marker MDA and ROS production at high concentration of the agents tested suggesting it behaves as a prooxidant in this study. ROS have high chemical activity and they play important roles in the regulation of cell proliferation and apoptosis. The level of ROS and lipid peroxidation was highly increased in PC3 cells in response to antioxidants tested within this study in comparison with untreated control cells, as shown in Figure $2(p<0.001)$. These results suggest that $\alpha$-Toc, $\beta$-Crt and Asc induced mitochondrial dysfunction through the depolarization of the mitochondrial membrane potential and the generation of ROS, which resulted in lipid peroxidation in PC-3 cells. Apoptosis and necrosis are the two important types of cell death for which the molecular mechanisms have been widely studied [26]. Apoptosis, programmed cell death, is a normal developmental process that is characterized by nuclear condensation and cleavage of critical cellular proteins [27]. Apoptosis and necrosis represent two different mechanisms during cellular death. The dynamics of cellular lesions in these two processes are different. It was previously reported that plasma membrane damage, occurring as a primary event during necrosis represents, on the contrary, it is a delayed but massive phenomenon during apoptosis. One way to detect whether the antioxidants induced apoptosis or necrosis is to carry out caspase 3 staining. Therefore, in this research, in addition to investigation of cell viability and ROS and LPO production in PC-3 cell line, the expression of apoptotic caspase-3 enzyme (protease enzyme that play a key role in apoptosis) was studied by immunohistochemical staining. As shown in Figure 4, treatment of PC-3 cells with $\alpha-T o c, \beta-C r t$ and Asc displayed a marked increase in the expression level of caspase-3 suggesting the elevation in apoptotic enzyme by the antioxidants may account for the antiapoptotic effect.

\section{CONCLUSION}

This study investigated in vitro anticancer effect of $\alpha$-Toc, $\beta$-Crt and Asc on PC-3 prostate cancer cells by cell proliferation, ROS and Lipid Peroxidation assay, caspase-3 and propidium iodide staining experiments. The results confirmed that these molecules behaved as prooxidant by decreasing cell viability and increasing ROS and LPO levels in PC-3 cells. It was found that they induced apoptotic pathway as they increased expression level of apoptotic gene caspase-3.

\section{References}

1. K. Turkekul, R.D. Colpan, T. Baykul, M.D. Ozdemir, S. Erdogan, Esculetin inhibits the survival of human prostate cancer cells by inducing apoptosis and arresting the cell cycle, J. Cancer Prev., 23 (2018) 10-17.

2. A. Chomyn, G. Attardi, MtDNA mutations in aging and apoptosis, Biochem. Biophys. Res. Commun., 304(2003), 519-529.

3. G.D. Dakubo, R.L. Parr, L.C. Costello, R.B. Franklin, R.E. Thayer, Altered metabolism and mitochondrial genome in prostate cancer. J. Clin. Pathol., 59 (2006) 10-16.

4. N. Khurana, S. Sikka, Targeting crosstalk between Nrf-2, $\mathrm{NF}-\mathrm{KB}$ and androgen receptor signaling in prostate cancer Cancers, 10 (2018) 352.

5. G. Barrera, Oxidative stress and lipid peroxidation products in cancer progression and therapy, ISRN Oncol., 2012 (2012), $1-21$.

6. R.K. Khurana, A. Jain, A. Jain, T. Sharma, B. Singh, P. Kesharwani, Administration of antioxidants in cancer: debate of the decade, Drug Discov. Today, 23 (2018) 763770

7. A.A. de Carvalho Melo-Cavalcante, L. da Rocha Sousa, M.V.O.B. Alencar, J.V. de Oliveira Santos, A.M. oliveira da Mata, M.F.C. Paz, J. C.R. Gonçalves, Retinol palmitate and ascorbic acid: Role in oncological prevention and therapy, Biomed. Pharmacother., 109 (2019) 1394-1405.

8. C. Sato, S. Kaneko, A. Sato, N. Virgona, K. Namiki, T. Yano, Combination Effect of $\delta$-Tocotrienol and $y$-Tocopherol on Prostate Cancer Cell Growth. J. Nutr. Sci. Vitaminol., 63 (2017) 349-354. 
9. S.B. Nimse, D. Pal, Free radicals, natural antioxidants, and their reaction mechanisms. Rsc Adv., 5 (2015) 27986-28006.

10. P.K. Witting, J.M. Upston, R. Stocker, Role of $\alpha$-tocopheroxyl radical in the initiation of lipid peroxidation in human lowdensity lipoprotein exposed to horse radish peroxidase, Biochem., 36 (1997) 1251-1258.

11. P. Morlière, L.K, Patterson, C.M. Santos, A.M. Silva, J.C. Mazière, P. Filipe, R. Santus, The dependence of $\alpha$-tocopheroxyl radical reduction by hydroxy-2, 3 -diarylxanthones on structure and micro-environment, Org. Biomol. Chem., 10 (2012) 2068-2076.

12. R. Stocker, V.W. Bowry, B. Frei, Ubiquinol-10 protects human low density lipoprotein more efficiently against lipid peroxidation than does alpha-tocopherol, Proc. Natl. Acad. Sci. U.S.A., 88 (1991) 1646-1650.

13. E. Niki, Role of vitamin $\mathrm{E}$ as a lipid-soluble peroxyl radical scavenger: in vitro and in vivo evidence, Free. Radic. Biol. Med., 66 (2014) 3-12.

14. E. Niki, Action of ascorbic acid as a scavenger of active and stable oxygen radicals, Am. J. Clin. Nutr., 54 (1991) 11191124.

15. K.L. Retsky, M.W. Freeman, B. Frei, Ascorbic acid oxidation product (s) protect human low density lipoprotein against atherogenic modification. Anti-rather than prooxidant activity of vitamin $\mathrm{C}$ in the presence of transition metal ions, J. Biol. Chem., 268 (1993) 1304-1309.

16. C.W. Oh, M. Li, E.H, Kim, J.S. Park, J.C. Lee, S.W. Ham, Antioxidant and radical scavenging activities of ascorbic acid derivatives conjugated with organogermanium, Bull. Korean Chem. Soc., 31 (2010) 3513-3514.

17. J.A. Satia, A. Littman, C.G. Slatore, J.A. Galanko, E. White, Long-term use of $\beta$-carotene, retinol, lycopene, and lutein supplements and lung cancer risk: Results from the vitamins and lifestyle (VITAL) study, Am. J. Epidemiol., 169 (2009) 815-828.

18. M.T. Smith, H. Thor, P. Hartzell, S. Orrenius, The measurement of lipid peroxidation in isolated hepatocytes, Biochem. Pharmacol., 1 (1982) 19-26.
19. M. Tartik, E. Darendelioglu, G. Aykutoglu, G. Baydas, Turkish propolis supresses MCF-7 cell death induced by homocysteine, Biomed. Pharmacother., 82 (2016) 704-712.

20. B. Poljsak, D. Šuput, I. Milisav, Achieving the balance between ROS and antioxidants: when to use the synthetic antioxidants, Oxid. Med. Cell. Longev., 2013 (2013).

21. F. Hecht, C.F. Pessoa, L.B. Gentile, D. Rosenthal, D.P. Carvalho, R.S. Fortunato, The role of oxidative stress on breast cancer development and therapy, Tumor Biol., 37 (2016) 4281-4291.

22. G.E. Goodman, M.D. Thornquist, J. Balmes, M.R. Cullen, F.L. Meyskens Jr, G.S. Omenn, J.H. Williams Jr, The BetaCarotene and Retinol Efficacy Trial: incidence of lung cancer and cardiovascular disease mortality during 6-year followup after stopping $\beta$-carotene and retinol supplements, J. Natl. Cancer Inst., 96 (2004) 1743-1750.

23. W.G. Christen, J.M. Gaziano, C.H. Hennekens, PHYSICIANS, F. T. S. C. O., \& STUDY II, H. E. A. L. T. H., Design of Physicians' Health Study II-a randomized trial of beta-carotene, vitamins $\mathrm{E}$ and $\mathrm{C}$, and multivitamins, in prevention of cancer, cardiovascular disease, and eye disease, and review of results of completed trials, Ann. Epidemiol., 10 (2000) 125134.

24. E.A. Klein, I.M. Thompson, C.M. Tangen, J.J. Crowley, M.S. Lucia, P.J. Goodman, D.D. Karp, Vitamin E and the risk of prostate cancer: the Selenium and Vitamin E Cancer Prevention Trial (SELECT), JAMA, 306 (2011) 1549-1556.

25. Y. Cui, Z. Lu, L. Bai, Z. Shi, W.E. Zhao, B. Zhao, $\beta$-Carotene induces apoptosis and up-regulates peroxisome proliferatoractivated receptor $\gamma$ expression and reactive oxygen species production in MCF-7 cancer cells, Eur. J. Cancer, 43 (2007) 2590-2601.

26. V. Nikoletopoulou, M. Markaki, K. Palikaras, N. Tavernarakis, Crosstalk between apoptosis, necrosis and autophagy, Biochim. Biophys. Acta- Mol. Cell Res., 1833 (2013) 34483459

27. J.J. Stevens, B. Graham, E. Dugo, B. Berhaneselassie-Sumner, K. Ndebele, P.B. Tchounwou, Arsenic trioxide induces apoptosis via specific signaling pathways in HT-29 colon cancer cells, J. Cancer Sci. Ther., 9 (2017) 298. 